\title{
Evaluation of heavy metals content in dietary supplements in Lebanon
}

\author{
Samira Ibrahim Korfali ${ }^{1 *}$, Tamer Hawi ${ }^{1}$ and Mohamad Mroueh ${ }^{2}$
}

\begin{abstract}
Background: The consumption of dietary supplements is widely spread and on the rise. These dietary supplements are generally used without prescriptions, proper counseling or any awareness of their health risk. The current study aimed at analyzing the metals in 33 samples of imported dietary supplements highly consumed by the Lebanese population, using 3 different techniques, to ensure the safety and increase the awareness of the citizen to benefit from these dietary supplements.

Results: Some samples had levels of metals above their maximum allowable levels (Fe: 24\%, Zn: 33\%, Mn: 27\%, Se: $15 \%$, Mo: $12 \%$ of samples), but did not pose any health risk because they were below permitted daily exposure limit and recommended daily allowance except for Fe in $6 \%$ of the samples. On the other hand, 34\% of the samples had Cu levels above allowable limit where 18\% of them were above their permitted daily exposure and recommended daily allowance. In contrast, all samples had concentration of $\mathrm{Cr}, \mathrm{Hg}$, and $\mathrm{Pb}$ below allowable limits and daily exposure. Whereas, $30 \%$ of analyzed samples had levels of $\mathrm{Cd}$ above allowable levels, and were statistically correlated with $\mathrm{Ca}$, and Zn essential minerals. Similarly $62 \%$ of the samples had levels of As above allowable limits and As levels were associated with Fe and Mn essential minerals.

Conclusion: Dietary supplements consumed as essential nutrients for their $\mathrm{Ca}$, Zn, Fe and Mn content should be monitored for toxic metal levels due to their natural geochemical association with these essential metals to provide citizens the safe allowable amounts.
\end{abstract}

Keywords: Dietary supplements, Heavy metals, Daily intake, Health/risk factor, XRF, Lebanon

\section{Background}

Over the years the pharmaceutical industry has been one of the most stable industries in the world, manufacturing a wide range of therapeutic agents and dietary supplements. While the use of therapeutic agents and prescribed medications are considered essential to resist against many diseases [1]; dietary supplements are consumed to extend our diet with needed vitamins, minerals, herbs and amino acids for optimal body function [2,3].

Nowadays, the utilization of multivitamins or multiminerals preparations is widely spread to increase the daily intake of essential micronutrient. In the Unites States, it has been estimated that approximately $40 \%$ of the population consumes vitamins and/or mineral preparations [4]. Calcium, iron, manganese, zinc and copper are among

\footnotetext{
* Correspondence: skorfali@lau.edu.lb

'Lebanese American University, P.O.Box 13-5053, Chouran Beirut, 11022801 Beirut, Lebanon

Full list of author information is available at the end of the article
}

these elements and are of great importance to our daily body functions due to their physiological and biological roles. The essentiality of $\mathrm{Cu}$ and $\mathrm{Zn}$ is based on its role as cofactor of a large number of enzymes [3-5]. Manganese is also a vital mineral, needed for normal growth; it helps breakdown fats, carbohydrates and proteins, and serves as co-factor for enzymes [5]. However, an increase in intake above recommended limit and daily allowance (RDA) for Mn (2-5 mg/day), $\mathrm{Zn}(8 \mathrm{mg} /$ day female and $11 \mathrm{mg} /$ day male) and $\mathrm{Cu}(1.5-3 \mathrm{mg} /$ day) may result in toxic effects $[3,5,6]$. A high supplement of $\mathrm{Cu}$ has been related with liver damage and overdoses of $\mathrm{Zn}$ may weaken the immune system, reduce HDL levels (good cholesterol) and induce seizure [3-5]. High levels of Mn can pose a neurotoxic threat and chronic intake of high doses can cause Parkinson's like symptoms [5]. Although the mechanism of action of $\mathrm{Cr}$ in the body and the amounts needed for optimal health care are not well defined, yet it is required in trace amounts. The biologically active form $\mathrm{Cr}^{3+}$ is
(C) Chemistry Central

(c) 2013 Korfali et al.; licensee Chemistry Central Ltd. This is an Open Access article distributed under the terms of the Creative Commons Attribution License (http://creativecommons.org/licenses/by/2.0), which permits unrestricted use, distribution, and reproduction in any medium, provided the original work is properly cited. 
believed to enhance the action of insulin [7], while $\mathrm{Cr}^{6+}$ is toxic and results from industrial pollution. Few serious adverse effects have been linked to high intake of $\mathrm{Cr}$, and WHO [8] considered that supplements with chromium should not exceed $250 \mu \mathrm{g} /$ day. But the recommended daily allowance (RDA) set by the Food and Drug Administration (FDA) is $35 \mu \mathrm{g} /$ day [6]. Mo and Se are also essential minerals. Molybdenum is a component of important enzyme systems [2], and Se is incorporated into proteins producing important antioxidant enzymes the selenoproteins. The adverse health effects of selenium or selenium toxicity (selenosis) are hair and nail brittleness and other symptoms such as gastrointestinal disturbances, fatigue and irritability $[9,10]$. The recommended daily allowance (RDA) according to the Institute of Medicine (IOM) is $55 \mu \mathrm{g} /$ day [11].

On the other hand, heavy metals such as $\mathrm{Pb}, \mathrm{Hg}, \mathrm{Cd}$, and As are toxic at much lower levels. Lead is known to induce renal tumors, reduce cognitive development, increase blood pressure and cardiovascular diseases in adults. The human brain is most affected by lead intake. Children appear to be especially sensitive to lead, and lead exposure has been correlated to decreased IQ and poor learning in children [2,3,12-14]. Organic mercury is more toxic than inorganic form since it is more readily absorbed through ingestion; it is very harmful to fetal and children developments [15]. However, high exposure to organic and inorganic mercury may cause neurological disorders including seizures and even death [3]. Cadmium excessive intake affects mostly the kidney and to a lower extent the reproductive system [3], while that of arsenic is known to cause cancer [16], impairment of the reproductive system [17], and atherosclerosis [18]. The US Pharmacopeia [19] in its latest revision of metal limit has set the oral permitted daily exposure (PDE) from drugs and dietary supplements to be for: $\mathrm{Pb} 5 \mu \mathrm{g} /$ day, $\mathrm{Hg}$ $15 \mu \mathrm{g} /$ day, Cd $25 \mu \mathrm{g} /$ day, and As $1.5 \mu \mathrm{g} /$ day (previously set at $15 \mu \mathrm{g} /$ day by USP in 2008 [20]).

The manufacturing of medicinal products requires extensive quality control, including the control of all manufacturing phases until the final product. Some countries have set strict quality control regulations and many others failed [21]. Several regulatory agencies highlighted that some dietary supplements may induce health problems with regard to their quality, effectiveness and safety for human consumption [22]. Poor quality control increases the risk of contamination of these products by bacteria, fungi, heavy metals and metalloids [21,23].

Many analytical techniques have been developed to determine different methods of metal concentration. Tumir et al. [21] used microwave digestion and Atomic Absorption Spectrometry to find the concentration of $\mathrm{Pb}, \mathrm{Cd}, \mathrm{As}, \mathrm{Hg}, \mathrm{Cr}, \mathrm{Ni}$, and Zn. Kaufman et al. [12] determined lead content of dietary supplements by ICP-MS. The approved FDA method is the ICP. However, a proposed protocol is set to acknowledge the recent EDXRF technique (Energy dispersive XRF, using X-ray tubes as an excitation source) if the samples have toxic metal concentrations greater than $10 \mathrm{ppm}$ [24]. Better detection limits and more elements would be obtained using X-ray tubes as excitation sources instead of radionuclide sources. With modern software's, it is possible to produce clean spectra with net peak intensities, and precise corrections for inter-element matrix effects [25]. Though literature cites limited use of XRF for determining metals in dietary tablets, yet XRF has been widely used for applications in metal analysis of alloys, soils, $\mathrm{Pb}$ in paints and $\mathrm{Cd}$ in plastics. It has been used for monitoring trace metals in milk [26], metals in oysters [27], trace metals in fruit juices [28], metals in oriental spices [29]. Additionally, Anderson [30], an FDA researcher, used hand-held XRF analyzer for determining toxic elements in tableware. While Chuparina and Aisueva [31] determined heavy metals in medicinal plants using XRF, as well as Bueno and Romão [32] determined $\mathrm{P}, \mathrm{Ca}, \mathrm{Ti}$ and $\mathrm{Fe}$ in counterfeit medicines.

Lebanese are becoming more health conscious and nutritional supplements have become a vital part of their daily diet, which led to a growing demand for dietary supplements including vitamins and minerals. This increase is due to the consumers' beliefs that these products are natural and safe and devoid of any adverse effects. Unfortunately, this trust made most consumers use these dietary supplements without proper counseling and monitoring. Regulatory agencies in Lebanon highlighted the problems with dietary supplements in terms of quality, effectiveness and safety. However, these regulations are not implemented and not strictly enforced. Thus the objective of the current study is to evaluate metal content and metal contamination in dietary supplements available in Lebanese market (imported goods) using XRF technique and digestion/AAS technique, and ensure the safety and awareness of the citizens regarding these dietary supplements.

\section{Results and discussion}

\section{Dietary samples characteristics}

Thirty three dietary supplement tablets of Vitamin, Vitamins and Minerals, Minerals, and Herbs were purchased from local pharmacies. The brands were selected based on two criteria: first that they contain either metals only and/or metals as their main constituent, second for their popularity among the Lebanese citizens. The samples were coded according to their main dietary supplements: Vitamins were coded as V (3 samples), Vitamins and Minerals as VM (13 samples), Minerals as M (7 samples), and Herbs as $H$ (10 samples). Table 1 represents the manufacturing country, usage and content as indicated on each Label. 
Table 1 Characteristics of dietary tablets

\begin{tabular}{|c|c|c|c|}
\hline Sample ID & Origin & Therapeutic indication & Main ingredients \\
\hline \multicolumn{4}{|l|}{ Vitamins } \\
\hline V1 & Italy & healthy shiny hair & Niacin,Folic Acid, Vitamin B-12, Silica, \\
\hline V2 & USA & Improve microcirculation & Vitamin C, E, Creatine, Ginseng cert \\
\hline V3 & Belgium & physical and mental fatigue & Vitamin A, B6, B12, C, Ca, P, Zn, Cr \\
\hline \multicolumn{4}{|c|}{ Vitamins and Minerals } \\
\hline VM1 & UK & suitable for diabetics & Vitamin A,B1,B6, Folic acid, Fe, Zn, Mn, Se, Cu \\
\hline VM2 & USA & essential nutrients and anti-oxidants & Vitamin D, Ca \\
\hline VM3 & Denmark & Multivitamins and minerals for children & Vitamin A, B1,B12,D,E,Cu,Fe, Mn, Mo, Se, Zn, \\
\hline VM4 & Italy & 13 vitamins and 13 minerals & $\begin{array}{l}\text { Vitamin A, B1,B5, B6,B12,C,D,E, PP, Ca, Fe, Cr, Cu, } \\
\mathrm{Fe}, \mathrm{K}, \mathrm{Mn}, \mathrm{Mo}, \mathrm{Se}, \mathrm{Zn}\end{array}$ \\
\hline VM5 & USA & bones and teeth, prevent osteoporosis & Vitamin D3, Ca, magnesium silicate, mineral oil \\
\hline VM6 & UK & Multivitamins and minerals for adults 50 & Multi-Vitamins,Ca, Cu, Fe,K, Ginkgo Biloba \\
\hline VM7 & USA & Energizer multivitamin & $\begin{array}{l}\text { Multi-Vitamins, Ca, Cu, Fe,Mo, B, K, Ginseng, } \\
\text { Ginkgo Biloba, Green Tea, Spinach, }\end{array}$ \\
\hline VM8 & Switzerland & $\begin{array}{l}\text { antioxidant effect, vitamin and mineral for } \\
\text { vision and the eye }\end{array}$ & Beta-carotene, Vitamin B2, C, E, Cu, Se,Zn, Lutein \\
\hline VM9 & USA & supports heart health & Multi-Vitamins,Ca, Cu, Fe,Mo, B, K,P, V,Se,Ti, \\
\hline VM10 & UK & Mineral and Vitamins for pregnant women & Multi-Vitamins, Betacarotene, Cu,Fe, Zn \\
\hline VM11 & USA & Vitamin, mineral, herb formula for women & Multi-Vitamins, Ca, Cu, Fe, B, K,P, Se \\
\hline VM12 & USA & Vitamin, mineral, herb formula for men & Multi-Vitamins $\mathrm{Ca}$, Cu, K, Mn, Se, Zn \\
\hline VM13 & USA & $\begin{array}{l}\text { Vitamins and mineral formula for pregnant } \\
\text { and lactating women }\end{array}$ & Vitamin A,B1, B2,B6,B12,C,D,Folic acid, Ca, Mg, Zn, \\
\hline \multicolumn{4}{|l|}{ Minerals } \\
\hline M1 & USA & Calcium and Magnesium supplement & Ca- from calcium carbonate and oyster shells \\
\hline M2 & USA & bones and help prevent osteoporosis & $\mathrm{Ca}, \mathrm{Mg}, \mathrm{Zn}$, eggshells and mineral oil \\
\hline M3 & USA & Calcium supplement & $\mathrm{Ca}, \mathrm{Mg}, \mathrm{Cu}, \mathrm{Mn}$ \\
\hline M4 & Italy & Food supplement with fossil coral & Ca, Mg, Fossil coral powder \\
\hline M5 & UK & Helps maintain energy levels & $\mathrm{Ca}, \mathrm{Mg}, \mathrm{Zn}$ \\
\hline M6 & USA & Promotes sleep, and calm mental and stress & $\mathrm{Ca}, \mathrm{Mg}$, Valerian \\
\hline M7 & USA & Milk and dairy digestant & Lactase Enzyme,Soybean Oil \\
\hline \multicolumn{4}{|l|}{ Herbs } \\
\hline $\mathrm{H} 1$ & USA & Memory Disorder & Ginkgo Biloba (dried Leaf and powder) \\
\hline $\mathrm{H} 2$ & USA & Digestive function & Pancreatin, Protease (Papain), Papaya Fruit Powder \\
\hline H3 & UK & Immune system & Stearic acid, beta-carotene selenium yeast \\
\hline H4 & USA & Immune function & Vegetable Stearic acid,and magnesium stearate, \\
\hline H5 & Italy & Urinary ducts & Proanthocyandian, bearberry and ortosiphon leaves \\
\hline H6 & Italy & Llight and moderate state of depression & $\begin{array}{l}\text { L-Tryptophan, Vitamin PP, L-Tyrosine, L-Phenylalaninr, } \\
\text { Vitamin B6 }\end{array}$ \\
\hline H7 & USA & Support joint lubrication, & Hydrolized chicken sternal cartilage, Hyaluronic acid \\
\hline H8 & Italy & metabolic process & Ginkgo Biloba leaves \\
\hline H9 & USA & Memory Disorder & Ginkgo Biloba dried leaf and extract \\
\hline $\mathrm{H} 10$ & Canada & Aids in digestion & Amylase, bromelain, papain, papaya \\
\hline
\end{tabular}




\section{Concentrations of micronutrients with a high upper intake limit}

The most abundant elements in the dietary samples were iron and zinc, followed by Mn. These metals are classified by USP stimuli article "General Chapter on Inorganic Impurities: heavy metals, Pharmacopeia form $34 / 5$ " as class IV that is recognized as micronutrient with a high upper intake limit [33]. Table 2 presents the concentration of $\mathrm{Fe}, \mathrm{Zn}$ and $\mathrm{Mn}$ in studied samples and the maximum allowable levels (MAL) proposed by the Expert Committee in USP Advisory Panel on Inorganic Impurities and Heavy metals [34]. It also includes the recommended daily allowance (RDA) set by the Food and Drug Administration (FDA) [6], the permitted daily exposure (PDE) recommended by US Pharmacopeia, and permissible daily intake set by WHO/FAO calculated using provisional tolerable intake for a body weight of $60 \mathrm{~kg}$ and allocating $10 \%$ of this to be due to dietary supplement as indicated in Dietary Supplement -Standard 173 [35].

The mean levels for Fe, $\mathrm{Zn}$ and $\mathrm{Mn}$ were 2690, 2133 and $305 \mu \mathrm{g} / \mathrm{g}$, respectively. The highest levels of these metals were in Vitamins and Minerals with respectively mean levels of 6145,4478 and $696 \mu \mathrm{g} / \mathrm{g}$, and were above their respective maximum allowable level (MAL) of 1500, 1500 and $250 \mu \mathrm{g} / \mathrm{g}$ [34]. Additionally, 7 (45\%) of the Vitamins and Mineral samples had levels of these metals above their recommended MAL. For example, VM10, had the highest level of Fe $(21280 \mu \mathrm{g} / \mathrm{g}), 14$ times more than it's MAL, and this product is advised as a supplement during pregnancy. The daily intake of iron from this product is $15,534 \mu \mathrm{g} /$ day, and it slightly exceeds the maximum PDE $(15000 \mu \mathrm{g} /$ day $)$, and is twice the FDA recommended daily allowance of $8000 \mu \mathrm{g} /$ day. Similarly, VM13, an advised vitamin and mineral formula for pregnancy and lactation, had a high level of Fe $(13,494 \mu \mathrm{g} / \mathrm{g})$ and its daily recommended intake is $19161 \mu \mathrm{g} /$ day (1.3 times its PDE, and 2.3 times more than its RDA), while VM4 had Fe level of $11789 \mu \mathrm{g} / \mathrm{g}$, but its daily intake $(5894 \mu \mathrm{g} /$ day $)$ is below the recommended RDA and PDE levels. But compared to permissible daily intake by WHO/FAO [36] from provisional tolerable daily intake of $0.8 \mathrm{mg} / \mathrm{kg}$ body weight, for $60 \mathrm{~kg}$ and allocating $10 \%$ to dietary sample[35], then $24 \%$ of samples are above permissible levels. Nevertheless according to the National Institute of Health, Office of Dietary Supplements [1], the recommended daily allowance (RDA) for women is $18 \mathrm{mg} /$ day, $27 \mathrm{mg} /$ day during pregnancy and $10 \mathrm{mg} /$ day for lactating women. Both products with high Fe content (VM10 and VM13) are recommended during pregnancy and lactation and do not pose any health concern in terms of Fe levels, because it is still below Tolerable Upper Intake levels (45,000 $\mu \mathrm{g} /$ day).

The highest level of $\mathrm{Zn}$ was found in VM8 (16054 $\mu \mathrm{g} / \mathrm{g})$ which is about 10 times more than its recommended maximum allowable level-MAL $(1500 \mu \mathrm{g} / \mathrm{g})$ and its daily intake $(21673 \mu \mathrm{g} /$ day $)$ exceeds the set PDE $(15000 \mu \mathrm{g} /$ day $)$, and is twice the set RDA value (Table 2). This product labeled as antioxidant, contains minerals and vitamins needed for healthy vision. Moreover 33\% of all samples and $61 \%$ of Vitamin and Minerals samples had levels of $\mathrm{Zn}$ above their recommended MALs. Though $\mathrm{Zn}$ is an essential constituent of many enzymes, needed for protein synthesis, and energy metabolism, yet excess intake may lead to electrolyte imbalance and nausea [37]. The Office of Dietary Supplements [1] of the National Institute of Health set a daily requirement for zinc between $8-12 \mathrm{mg} /$ day for adults. As such, the highest daily intake of $\mathrm{Zn}$ in sample MV8 exceeds the RDA value, but is still below Tolerable Upper Intake levels (40 mg/day), and hence there is no health risk of $\mathrm{Zn}$ intake in all these samples. Also $12 \%$ of samples exceeded WHO permissible limits based on provisional tolerable daily intake for $60 \mathrm{~kg}$ body weight and $10 \%$ allocation to dietary supplements [35,38]. Compared to previous studies including multivitamin/mineral supplements, the reported $\mathrm{Zn}$ levels in this study were higher than those in dietary supplements in Mexican market (2.83- $4786 \mu \mathrm{g} / \mathrm{g}$ [3]; but were comparable to Avula et al. [39] with $\mathrm{Zn}$ ranges were between 170 and $22,500 \mu \mathrm{g} /$ serving.

The mean level of $\mathrm{Mn}$ in all samples was $305 \mu \mathrm{g} / \mathrm{g}$ and is higher than its maximum allowable level (MAL). Similar to $\mathrm{Fe}$ and $\mathrm{Zn}$, the Mn levels were highest in Vitamins and Minerals supplements, with a mean level of $696 \mu \mathrm{g} / \mathrm{g}$. Mn content was very high in sample VM1 with a value of 2028 $\mu \mathrm{g} / \mathrm{g}$, exceeding by about 8 times the MAL $(250 \mu \mathrm{g} / \mathrm{g})$ set value. The therapeutic indication of VM1, as per label, is "essential vitamins and minerals needed for diabetics". Nevertheless, the Mn daily intake in all samples was below their PDE set levels $(2500 \mu \mathrm{g} /$ day $)$, and hence do not pose a health concern. Literature review shows that the reported Mn levels in multivitamin/mineral supplements are within the studied range as reported by Avula et al. [39] with an Mn range of 78 and 17,500 $\mu \mathrm{g} /$ serving.

The three metals showed a statistical significant correlation among studied samples (for $\mathrm{Fe}$ and $\mathrm{Zn}, \mathrm{r}=0.672$, $\mathrm{p}<0.01$; Fe and $\mathrm{Mn} \mathrm{r}=0.554, \mathrm{p}<0.01$, and $\mathrm{Zn}$ and $\mathrm{Mn}$ $r=0.518, p<0.01)$. Thus either these minerals are added each as a supplement and/or they are geochemically associated to each other. Iron and Mn belong to the same class being considered geochemically as reducible fractions forms, and $\mathrm{Zn}$ is highly adsorbed and associated with these reducible fractions [40-42].

\section{Concentrations of micronutrients with low established upper intake limit}

Copper, Cr, Mo, and Se metals are classified by USP stimuli article "General Chapter on Inorganic Impurities: Heavy metals, Pharmacopeia form $34 / 5$ " as class III and are recognized as micronutrient with a low established 


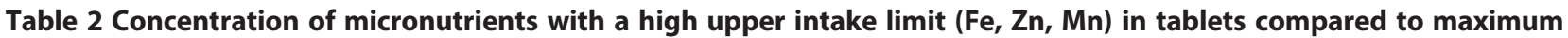
accepted level, and daily intake (DI) as recommended on tablet label and compared to recommended daily allowance and permitted levels

\begin{tabular}{|c|c|c|c|c|c|c|}
\hline Sample ID & $\mathrm{Fe}(\mu \mathrm{g} / \mathrm{g})$ & $\mathrm{DI}^{*}(\mu \mathrm{g} /$ day) $\mathrm{Fe}$ & $\mathrm{Zn}(\mu \mathrm{g} / \mathrm{g})$ & $\mathrm{DI}^{*}(\mu \mathrm{g} /$ day $) \mathrm{Zn}$ & $M n(\mu g / g)$ & $\mathrm{DI}^{*}$ ( $\mu \mathrm{g} /$ day) $\mathrm{Mn}$ \\
\hline V1 & 1120 & 3841 & 3570 & 12245 & 328 & 1124 \\
\hline V2 & 346 & 252 & 14 & 10 & 5.5 & 4 \\
\hline V3 & 1836 & 2295 & 396 & 494 & 2.5 & 3 \\
\hline VM1 & 9439 & 6513 & 9986 & 6890 & 2028 & 1399 \\
\hline VM2 & 7659 & 12637 & 1918 & 3164 & 8.7 & 1396 \\
\hline VM3 & 5801 & 5743 & 1199 & 1187 & 743 & 735 \\
\hline VM4 & 11788 & 5894 & 5108 & 3554 & 1962 & 981 \\
\hline VM5 & 36 & 55 & 3.5 & 5 & 17 & 25 \\
\hline VM6 & 2420 & 4654 & 1839 & 2776 & 10 & 15 \\
\hline VM7 & 9389 & 15117 & 2784 & 4482 & 1409 & 2269 \\
\hline VM8 & 72 & 97 & 16054 & 21673 & 3.5 & 5 \\
\hline VM9 & 41 & 62 & 3136 & 4705 & 852 & 1278 \\
\hline VM10 & 21280 & 15534 & 9895 & 6566 & 132 & 96 \\
\hline VM11 & 1942 & 8465 & 823 & 3586 & 361 & 1575 \\
\hline VM12 & 35 & 128 & 1307 & 4731 & 639 & 2315 \\
\hline VM13 & 13494 & 19162 & 5067 & 7195 & 43 & 62 \\
\hline M1 & 82 & 253 & 2.1 & 7 & 63 & 196 \\
\hline M2 & 24 & 31 & 961 & 1250 & 4.4 & 5.2 \\
\hline M3 & 56 & 212 & 1263 & 4799 & 480 & 1826 \\
\hline M4 & 58 & 186 & 3.5 & 11 & 14 & 45 \\
\hline M5 & 6 & 24 & 806 & 3553 & 6.5 & 29 \\
\hline M6 & 68 & 133 & 6.7 & 13 & 13 & 25 \\
\hline M7 & 25 & 70 & 6.1 & 8 & 8.2 & 11 \\
\hline $\mathrm{H} 1$ & 578 & 399 & 3.3 & 3 & 12 & 8 \\
\hline $\mathrm{H} 2$ & 50 & 65 & 1.1 & 1.4 & 1.1 & 0.7 \\
\hline H3 & 888 & 462 & 10.5 & 5.5 & 1.0 & 0.5 \\
\hline $\mathrm{H} 4$ & 5 & 3 & 4452 & 2894 & 1.5 & 0.9 \\
\hline H5 & 85 & 66 & 8.4 & 6.5 & 59 & 46 \\
\hline H6 & 47 & 34 & 2.0 & 1.5 & 4.5 & 3 \\
\hline $\mathrm{H} 7$ & 26 & 19 & 10.5 & 7.7 & 5.3 & 4 \\
\hline H8 & 47 & 25 & 2.9 & 1.6 & 6.2 & 3 \\
\hline H9 & 15 & 5 & 1.0 & 0.3 & 2.1 & 0.6 \\
\hline $\mathrm{H} 10$ & 27 & 14 & 1.8 & 0.9 & 3.3 & 1.5 \\
\hline$M A L^{* *}$ & $1500^{a}$ & - & $1500^{a}$ & - & $250^{\mathrm{b}}$ & \\
\hline $\mathrm{PDE}^{\dagger}$ & - & $15000^{a}$ & - & $15000^{a}$ & & $2500^{b}$ \\
\hline \multirow[t]{2}{*}{$\mathrm{RDA} / \mathrm{FDA}^{\ddagger}$} & - & $8000^{c}$ & - & $8000^{\complement}$ (female) & - & - \\
\hline & & & & $11000^{c}$ (male) & & \\
\hline $\mathrm{WHO} / \mathrm{FAO}^{\ddagger \neq}$ & - & $4800^{d}$ & - & $6000^{e}$ & - & - \\
\hline
\end{tabular}

*DI: daily intake calculated from mass of tablet and labeled recommended tablets per day.

**MAL: Maximum accepted levels of metals in Tablets $(\mu \mathrm{g} / \mathrm{g}$ )according to US Pharmacopeia (USP).

${ }^{\dagger}$ PDE: Permitted Daily exposure ( $\mu \mathrm{g} /$ day) according to US Pharmacopeia (USP).

${ }^{\ddagger} \mathrm{RDA}$ : Recommended daily allowance after FDA [6].

${ }^{\ddagger}$ WHO/FAO : Permissible daily intake calculated from using provisional tolerable intake and body weight of $60 \mathrm{~kg}$ and $10 \%$ due to dietary supplements [35].

${ }^{\mathrm{a}}$ USP [20] ${ }^{\mathrm{b}}$ USP [34] ${ }^{\mathrm{c}}$ FDA[6] ${ }^{\mathrm{d}}$ JECFA [36] ${ }^{\mathrm{e}}$ JECFA [38]. 
upper intake limit [33]. Hence, these elements are regarded essential nutrients with trace amounts, but become toxic at high concentrations. Table 3 presents the concentration of $\mathrm{Cu}, \mathrm{Cr}, \mathrm{Mo}$, and $\mathrm{Se}$ of studied samples, the maximum allowable levels (MAL), the recommended daily allowance (RDA), the permitted daily exposure (PDE), and the permissible daily intake of respective metals from dietary supplement.

The mean level of $\mathrm{Cu}$ in all samples was $277 \mu \mathrm{g} / \mathrm{g}$ which is higher than its recommended MAL $(100 \mu \mathrm{g} / \mathrm{g})$, $34 \%$ (12 samples) of samples having concentrations above allowable levels. The highest $\mathrm{Cu}$ levels were in Vitamins and Mineral samples, with a mean of $635 \mu \mathrm{g} / \mathrm{g}$, with $54 \%$ of these samples exceeding MAL values. The highest $\mathrm{Cu}$ level was found in VM $8(1952 \mu \mathrm{g} / \mathrm{g})$ and exceeds by 20 times the set MAL level. The indication of this product as per label is "vitamins and mineral salts necessary for healthy vision". Similarly, VM1 had high $\mathrm{Cu}$ content $(1583 \mu \mathrm{g} / \mathrm{g})$ and is indicated as "essential vitamins and minerals for diabetics". Two other samples, VM10 and VM7, had levels of 1270 and $867 \mu \mathrm{g} / \mathrm{g}$, and described as "essential vitamins and minerals for pregnant women", and "essential energizer multivitamins", respectively. The daily intake of $\mathrm{Cu}$ in VM 8, VM1 and VM7 are 2635, 1902 and $1396 \mu \mathrm{g} /$ day. All of these values are higher than the set PDE level of $1000 \mu \mathrm{g} /$ day [19], and RDA levels of $900 \mu \mathrm{g} /$ day [6], and WHO permitted daily intake of $300 \mu \mathrm{g} /$ day [38] calculated from provisional tolerable daily intake for a body weight of $60 \mathrm{~kg}$ and allocating $10 \%$ due to dietary supplements. Consequently, these brands should be controlled and advised for their usage. Compared to other works of multivitamins and minerals, our studied $\mathrm{Cu}$ levels in samples were within the range of $\mathrm{Cu}$ in various multivitamins and multi-minerals (1 $\mu \mathrm{g}-1981 \mu \mathrm{g}$ per serving) reported by Raman et al. [2].

Unlike other metals, the Cr levels in the tested samples were low. The mean level in all samples was $0.29 \mu \mathrm{g} / \mathrm{g}$ and it was highest in Vitamins and Minerals $(0.63 \mu \mathrm{g} / \mathrm{g})$. The highest $\mathrm{Cr}$ level was $5.5 \mu \mathrm{g} / \mathrm{g}$, thus 3 times less than its maximum allowable level (MAL) of $15 \mu \mathrm{g} / \mathrm{g}$. Chromium levels were also below those reported by Avula et al. [39] for multimineral and multivitamin supplements with a range between $4 \mu \mathrm{g} /$ serving and $248 \mu \mathrm{g} /$ serving.

The calculated mean value of Mo in Vitamins and Minerals of $10 \mu \mathrm{g} / \mathrm{g}$ is identical to the maximum allowable level (MAL) Table 3 [19]. Thirty percent of these samples had Mo levels higher than the MAL level, with the highest in sample VM9 of $44 \mu \mathrm{g} / \mathrm{g}$. This sample is constituted of vitamins and minerals and recommended for adults (above 50) to support heart health. VM7, classified also as an energizer multivitamin, had a level of $35 \mu \mathrm{g} / \mathrm{g}$. Nevertheless, the daily intake ( $\mu \mathrm{g} /$ day) of Mo in all samples was below the permitted daily exposure limit (PDE) of $100 \mu \mathrm{g} /$ day [19]. However, samples VM2
(43 $\mu \mathrm{g} /$ day), VM7 (57 $\mu \mathrm{g} /$ day), and VM9 (67 $\mu \mathrm{g} /$ day) exhibited daily intake above the recommended daily allowance (RDA) of $45 \mu \mathrm{g} /$ day for males and $34 \mu \mathrm{g} /$ day for females [6]. Thus these samples should be consumed with caution, not exceeding the recommended dose.

Though the mean level of Se $(19 \mu \mathrm{g} / \mathrm{g})$ is lower than the recommended set MAL $(25 \mu \mathrm{g} / \mathrm{g})$ value, yet four samples exhibited levels higher than $25 \mu \mathrm{g} / \mathrm{g}$. The highest Se level of $200 \mu \mathrm{g} / \mathrm{g}$ was in H3 sample (herbs category) and indicated to maintain a healthy immune system. The three other samples were VM1, with a Se level of $60 \mu \mathrm{g} / \mathrm{g}$, VM8 with $53 \mu \mathrm{g} / \mathrm{g}$, and VM2 with $31 \mu \mathrm{g} / \mathrm{g}$. Nevertheless all samples showed a daily intake level of Se below the permitted daily exposure (PDE) value of $250 \mu \mathrm{g} /$ day [20]. However, considering the Se RDA value of $55 \mu \mathrm{g} /$ day and its upper limit (UL) of $400 \mu \mathrm{g} /$ day [11], then samples VM8 with $72 \mu \mathrm{g}$ /day and H3 with $104 \mu \mathrm{g}$ /day are above the recommended daily intake value levels but far below the upper limit [11]. Still, tablets of H3 should be consumed cautiously.

\section{Concentrations of toxic elements}

Lead, $\mathrm{Hg}, \mathrm{Cd}$, and As are classified by USP stimuli article "General Chapter on Inorganic Impurities: Heavy metals, Pharmacopeial form $34 / 5$ ” as class I. These are metal impurities and generally recognized as presenting significant toxicity [33]. Table 4 presents the concentrations of $\mathrm{Pb}, \mathrm{Hg}$, $\mathrm{Cd}$, and $\mathrm{As}$ in studied samples, the maximum allowable levels (MAL), the permitted daily exposure (PDE), and the permissible daily intake of respective metal from dietary supplement. Since these metals are toxic, there are no recommended daily allowance levels.

The levels of lead and mercury in all dietary samples were low. The mean levels of $\mathrm{Pb}$ and $\mathrm{Hg}$ in all samples were respectively $0.11 \mu \mathrm{g} / \mathrm{g}$ and $0.08 \mu \mathrm{g} / \mathrm{g}$, with corresponding ranges of $0.01-0.41 \mu \mathrm{g} / \mathrm{g}$, and $0.01-0.55 \mu \mathrm{g} / \mathrm{g}$. Both $\mathrm{Pb}$ and $\mathrm{Hg}$ levels were lower than their maximum allowable levels (MAL) of $0.5 \mu \mathrm{g} / \mathrm{g}$ for $\mathrm{Pb}$, and of $1.5 \mu \mathrm{g} / \mathrm{g}$ for $\mathrm{Hg}$ [19]. These levels were also way below the permissible daily intake calculated from provisional tolerable weekly intake (PTWI) of $25 \mu \mathrm{g} / \mathrm{kg}$ body weight for $\mathrm{Pb}$ [38], and of $4 \mu \mathrm{g} / \mathrm{kg}$ body weight for $\mathrm{Hg}$ [43], adjusted per day for a $60 \mathrm{~kg}$ body weight and allocating 10\% for supplementary dietary tablets [35]. The levels of $\mathrm{Hg}(0.02-0.12 \mu \mathrm{g} / \mathrm{g})$ and $\mathrm{Pb}(0.25-3.86 \mu \mathrm{g} / \mathrm{g})$, in dietary supplementary tablets of vitamins and minerals and herbs, reported by Tumir et al. [21] are compatible with the $\mathrm{Hg}$ levels in this study, yet their $\mathrm{Pb}$ levels are much higher.

The mean level of $\mathrm{Cd}$ in all samples was found to be $1.8 \mu \mathrm{g} / \mathrm{g}$, with a range of 0.08 to $2.9 \mu \mathrm{g} / \mathrm{g}$. Eight of the samples had $\mathrm{Cd}$ levels above their maximum allowable level (MAL) of $2.5 \mu \mathrm{g} / \mathrm{g}$ as illustrated in Figure 1 . Furthermore, 4 of the Vitamins and Minerals samples had levels above the recommended MAL. The highest 
Table 3 Concentration of micronutrients with low established upper intake limit $(\mathrm{Cu}, \mathrm{Cr}, \mathrm{Mo}$, Se) in tablets compared to maximum accepted level, and daily intake (DI) as recommended on tablet label and compared to recommended daily allowance and permitted levels

\begin{tabular}{|c|c|c|c|c|c|c|c|c|}
\hline Sample ID & $\mathrm{Cu}(\mu \mathrm{g} / \mathrm{g})$ & $\mathrm{DI}^{*}(\mu \mathrm{g} /$ day $) \mathrm{Cu}$ & $\mathrm{Cr}(\mu \mathrm{g} / \mathrm{g})$ & $\mathrm{DI}^{*}(\mu \mathrm{g} /$ day $) \mathrm{Cr}$ & Mo $(\mu \mathrm{g} / \mathrm{g})$ & $\mathrm{DI}^{*}(\mu \mathrm{g} /$ day $) \mathrm{Mo}$ & Se $(\mu \mathrm{g} / \mathrm{g})$ & $\mathrm{DI}^{*}$ ( $\mu \mathrm{g} /$ day) Se \\
\hline V1 & 0.5 & 1.8 & 0.08 & 2.7 & 0.8 & 2.7 & 2.0 & 6.9 \\
\hline V2 & 9.0 & 6.6 & 0.04 & 0.03 & 3.4 & 2.4 & 0.1 & 0.08 \\
\hline V3 & 7.8 & 9.8 & 0.23 & 0.29 & 1.0 & 1.3 & 7.8 & 9.8 \\
\hline VM1 & 1583 & 1092 & 5.5 & 2.4 & 7.7 & 5.3 & 60.1 & 41.4 \\
\hline VM2 & 224 & 370 & 0.88 & 1.5 & 26 & 43 & 30.7 & 50.7 \\
\hline VM3 & 185 & 183 & 0.58 & 0.58 & 4.1 & 4.0 & 13.8 & 15.5 \\
\hline VM4 & 867 & 434 & 0.37 & 0.18 & 0.8 & 0.4 & 18.8 & 9.4 \\
\hline VM5 & 9.5 & 14.3 & 0.07 & 0.11 & 0.6 & 0.9 & 1.0 & 1.5 \\
\hline VM6 & 70 & 106 & 0.05 & 0.07 & 0.4 & 0.6 & 2.0 & 3.0 \\
\hline VM7 & 867 & 1396 & 0.31 & 0.49 & 35.4 & 57 & 24.9 & 40 \\
\hline VM8 & 1952 & 2635 & 0.02 & 0.03 & 13.3 & 18 & 52.9 & 71 \\
\hline VM9 & 725 & 1087 & 1.26 & 1.89 & 44.4 & 67 & 12.8 & 19 \\
\hline VM10 & 1270 & 927 & 0.17 & 0.12 & 0.5 & 0.4 & 0.9 & 0.7 \\
\hline VM11 & 225 & 979 & 0.54 & 2.30 & 0.6 & 2.6 & 7.3 & 32 \\
\hline VM12 & 281 & 1018 & 0.32 & 1.14 & 0.4 & 1.5 & 17.0 & 61 \\
\hline VM13 & 1.1 & 1.42 & 0.03 & 0.05 & 0.6 & 0.8 & 4.0 & 5.7 \\
\hline M1 & 6.9 & 22 & 0.06 & 0.20 & 0.7 & 2.2 & 2.1 & 6.2 \\
\hline M2 & 6.5 & 8.5 & 0.15 & 0.19 & 0.5 & 0.7 & 0.5 & 0.7 \\
\hline M3 & 376 & 1429 & 0.05 & 0.19 & 1.0 & 3.8 & 0.5 & 1.9 \\
\hline M4 & 7.9 & 25 & 0.13 & 0.41 & 0.3 & 1.0 & 1.1 & 3.2 \\
\hline M5 & 1.5 & 6.6 & 0.04 & 0.18 & 0.7 & 2.9 & 5.3 & 22 \\
\hline M6 & 8.8 & 17 & 0.10 & 0.19 & 0.8 & 1.6 & 2.2 & 3.9 \\
\hline M7 & 5.2 & 6.8 & 0.02 & 0.02 & 0.9 & 1.9 & 3.4 & 5.0 \\
\hline $\mathrm{H} 1$ & 8.5 & 5.8 & 0.08 & 0.05 & 1.1 & 0.7 & 1.1 & 0.7 \\
\hline $\mathrm{H} 2$ & 5.6 & 7.2 & 0.02 & 0.02 & 3.7 & 4.8 & 4.4 & 5.2 \\
\hline H3 & 3.8 & 2.0 & 0.03 & 0.02 & 0.5 & 0.3 & 200 & 104 \\
\hline $\mathrm{H} 4$ & 37 & 24 & 0.02 & 0.01 & 9.6 & 6.3 & 3.3 & 2.0 \\
\hline H5 & 15 & 12 & 0.09 & 0.07 & 7.5 & 5.8 & 3.1 & 2.3 \\
\hline $\mathrm{H} 6$ & 350 & 256 & 0.07 & 0.05 & 5.2 & 3.8 & 0.4 & 0.3 \\
\hline $\mathrm{H} 7$ & 16.5 & 12 & 0.02 & 0.01 & 6.5 & 4.7 & 0.3 & 0.2 \\
\hline $\mathrm{H} 8$ & 18.9 & 10 & 0.02 & 0.01 & 9.3 & 4.9 & 0.8 & 0.4 \\
\hline $\mathrm{H} 9$ & 5.8 & 1.8 & 0.07 & 0.02 & 0.1 & 0.03 & 4.1 & 1.3 \\
\hline $\mathrm{H} 10$ & 6.5 & 3.2 & 0.02 & 0.01 & 0.9 & 0.5 & 5.3 & 2.5 \\
\hline$M A L^{* *}$ & $100^{a}$ & & $15^{\mathrm{b}}$ & & $10^{a}$ & & $25^{c}$ & \\
\hline $\mathrm{PDE}^{\dagger}$ & & $1000^{a}$ & & $150^{b}$ & & $100^{\mathrm{a}}$ & & $250^{c}$ \\
\hline $\mathrm{RDA} / \mathrm{FDA}^{\ddagger}$ & & $900^{d}$ & & $35^{d}$ & & $34^{d}$ (male) $45^{d}$ (female) & & $55^{f}$ \\
\hline $\mathrm{WHO} / \mathrm{FAO}^{\ddagger \neq}$ & & $300^{e}$ & & - & & - & & - \\
\hline
\end{tabular}

${ }^{*} D I$ : daily intake calculated from mass of tablet and labeled recommended tablets per day.

**MAL: Maximum accepted levels of metals in Tablets ( $\mu \mathrm{g} / \mathrm{g}$ ) according to US Pharmacopeia (USP).

${ }^{\dagger}$ PDE: Permitted Daily exposure ( $\mu \mathrm{g} /$ day) according to US Pharmacopeia (USP).

${ }^{\ddagger} \mathrm{RDA}$ : Recommended daily allowance after FDA [6].

${ }^{\ddagger \neq}$ WHO/FAO : Permissible daily intake calculated from using provisional tolerable intake and body weight of 60 and $10 \%$ due to dietary supplements [35].

${ }^{\mathrm{a}}$ USP [19] ${ }^{\mathrm{b}}$ USP [34] ${ }^{\mathrm{C}}$ USP[20].

${ }^{d}$ FDA[6] ${ }^{\text {e }}$ JECFA [38] ${ }^{\text {f }}$ IOM [11]. 
Table 4 Concentration of toxic metals $(\mathrm{Pb}, \mathrm{Hg}, \mathrm{Cd}, \mathrm{As})$ in tablets compared to maximum accepted level, and daily intake (DI) as recommended on tablet label and compared to recommended daily allowance and permitted levels

\begin{tabular}{|c|c|c|c|c|c|c|c|c|}
\hline Sample ID & $\mathrm{Pb}(\mu \mathrm{g} / \mathrm{g})$ & $\mathrm{DI}^{*}$ ( $\mu \mathrm{g} /$ day) $\mathrm{Pb}$ & $\mathrm{Hg}(\mu \mathrm{g} / \mathrm{g})$ & $\mathrm{DI}^{*}(\mu \mathrm{g} /$ day $) \mathrm{Hg}$ & $C d(\mu g / g)$ & $\mathrm{DI}^{*}(\mu \mathrm{g} /$ day $) \mathrm{Cd}$ & As $(\mu \mathrm{g} / \mathrm{g})$ & $\mathrm{DI}^{*}$ ( $\mu \mathrm{g} /$ day) As \\
\hline V1 & 0.125 & 0.43 & 0.014 & 0.048 & 2.333 & 7.889 & 0.514 & 1.700 \\
\hline V2 & 0.161 & 0.12 & 0.015 & 0.011 & 0.552 & 0.401 & 0.095 & 0.069 \\
\hline V3 & 0.269 & 0.34 & 0.026 & 0.033 & 2.510 & 3.125 & 0.075 & 0.094 \\
\hline VM1 & 0.126 & 0.09 & 0.035 & 0.024 & 2.914 & 2.001 & 0.477 & 0.345 \\
\hline VM2 & 0.074 & 0.12 & 0.022 & 0.036 & 2.554 & 4.208 & 0.514 & 0.848 \\
\hline VM3 & 0.074 & 0.07 & 0.021 & 0.021 & 0.881 & 0.871 & 1.621 & 1.800 \\
\hline VM4 & 0.044 & 0.02 & 0.011 & 0.005 & 2.621 & 1.300 & 0.608 & 0.304 \\
\hline VM5 & 0.086 & 0.13 & 0.550 & 0.831 & 0.319 & 0.482 & 0.115 & 0.174 \\
\hline VM6 & 0.098 & 0.15 & 0.065 & 0.098 & 2.205 & 3.058 & 0.097 & 0.147 \\
\hline VM7 & 0.045 & 0.07 & 0.045 & 0.072 & 2.131 & 3.431 & 0.606 & 0.310 \\
\hline VM8 & 0.092 & 0.12 & 0.075 & 0.101 & 2.446 & 3.302 & 0.065 & 0.088 \\
\hline VM9 & 0.067 & 0.10 & 0.115 & 0.173 & 2.326 & 3.489 & 0.254 & 0.381 \\
\hline VM10 & 0.132 & 0.10 & 0.065 & 0.047 & 2.227 & 1.626 & 1.095 & 0.796 \\
\hline VM11 & 0.067 & 0.29 & 0.038 & 0.166 & 1.921 & 8.371 & 0.086 & 0.375 \\
\hline VM12 & 0.077 & 0.28 & 0.025 & 0.091 & 1.633 & 5.911 & 0.045 & 0.163 \\
\hline VM13 & 0.096 & 0.14 & 0.082 & 0.114 & 0.107 & 0.152 & 0.574 & 0.815 \\
\hline M1 & 0.071 & 0.22 & 0.093 & 0.278 & 0.821 & 2.537 & 0.013 & 0.038 \\
\hline M2 & 0.029 & 0.04 & 0.055 & 0.072 & 2.516 & 3.271 & 0.034 & 0.045 \\
\hline M3 & 0.071 & 0.27 & 0.044 & 0.167 & 1.820 & 6.916 & 0.057 & 0.217 \\
\hline M4 & 0.41 & 1.29 & 0.078 & 0.249 & 0.222 & 0.638 & 0.014 & 0.046 \\
\hline M5 & 0.012 & 0.05 & 0.015 & 0.066 & 2.139 & 9.433 & 0.068 & 0.300 \\
\hline M6 & 0.13 & 0.25 & 0.025 & 0.049 & 2.534 & 4.850 & 0.035 & 0.068 \\
\hline M7 & 0.097 & 0.13 & 0.044 & 0.054 & 0.196 & 0.143 & 0.066 & 0.089 \\
\hline $\mathrm{H} 1$ & 0.206 & 0.14 & 0.121 & 0.083 & 2.551 & 1.760 & 0.047 & 0.034 \\
\hline $\mathrm{H} 2$ & 0.109 & 0.14 & 0.255 & 0.329 & 1.493 & 1.922 & 0.055 & 0.071 \\
\hline $\mathrm{H} 3$ & 0.039 & 0.02 & 0.095 & 0.049 & 0.143 & 0.074 & 0.466 & 0.242 \\
\hline $\mathrm{H} 4$ & 0.247 & 0.16 & 0.085 & 0.055 & 0.540 & 0.351 & 0.699 & 0.454 \\
\hline H5 & 0.269 & 0.21 & 0.351 & 0.270 & 2.473 & 1.902 & 0.012 & 0.009 \\
\hline $\mathrm{H} 6$ & 0.029 & 0.02 & 0.243 & 0.175 & 0.294 & 0.288 & 0.023 & 0.017 \\
\hline $\mathrm{H} 7$ & 0.005 & 0.01 & 0.027 & 0.020 & 0.834 & 0.609 & 0.032 & 0.023 \\
\hline H8 & 0.045 & 0.02 & 0.011 & 0.006 & 0.599 & 0.317 & 0.076 & 0.040 \\
\hline H9 & 0.271 & 0.09 & 0.098 & 0.031 & 0.096 & 0.031 & 0.056 & 0.018 \\
\hline $\mathrm{H} 10$ & 0.058 & 0.03 & 0.011 & 0.005 & 0.086 & 0.042 & 0.022 & 0.011 \\
\hline$M A L^{* *}$ & $0.5^{a}$ & & $1.5^{\mathrm{a}}$ & & $2.5^{\mathrm{a}}$ & & $0.15^{a}$ & \\
\hline $\mathrm{PDE}^{\dagger}$ & & $5^{a}$ & & $15^{a}$ & & $25^{a}$ & & $1.5^{\mathrm{a}}$ \\
\hline \multicolumn{9}{|l|}{$\mathrm{RDA} / \mathrm{FDA}^{\ddagger}$} \\
\hline $\mathrm{WHO} / \mathrm{FAO}^{\ddagger \neq}$ & & $21.4^{b}$ & & $3.42^{c}$ & & $6^{d}$ & & $10^{e}$ \\
\hline
\end{tabular}

*DI: daily intake calculated from mass of tablet and labeled recommended tablets per day.

**MAL: Maximum accepted levels of metals in Tablets ( $\mu \mathrm{g} / \mathrm{g}$ )according to US Pharmacopeia (USP).

${ }^{\dagger}$ PDE: Permitted Daily exposure ( $\mu \mathrm{g} / \mathrm{day}$ ) according to US Pharmacopeia (USP) for $50 \mathrm{~kg}$ body weight.

${ }^{\ddagger}$ RDA: Recommended daily allowance after FDA [6].

${ }^{\ddagger}$ WHO/FAO : Permissible daily intake calculated from using provisional tolerable intake and body weight of $60 \mathrm{~kg}$ and $10 \%$ due to dietary supplements [35]. aUSP [19] ${ }^{\mathrm{b}}$ JECFA [38] ${ }^{\mathrm{c}}$ JECFA [43] ${ }^{\mathrm{d}}$ JECFA [47] ${ }^{\mathrm{e}}$ JECFA [50]. 


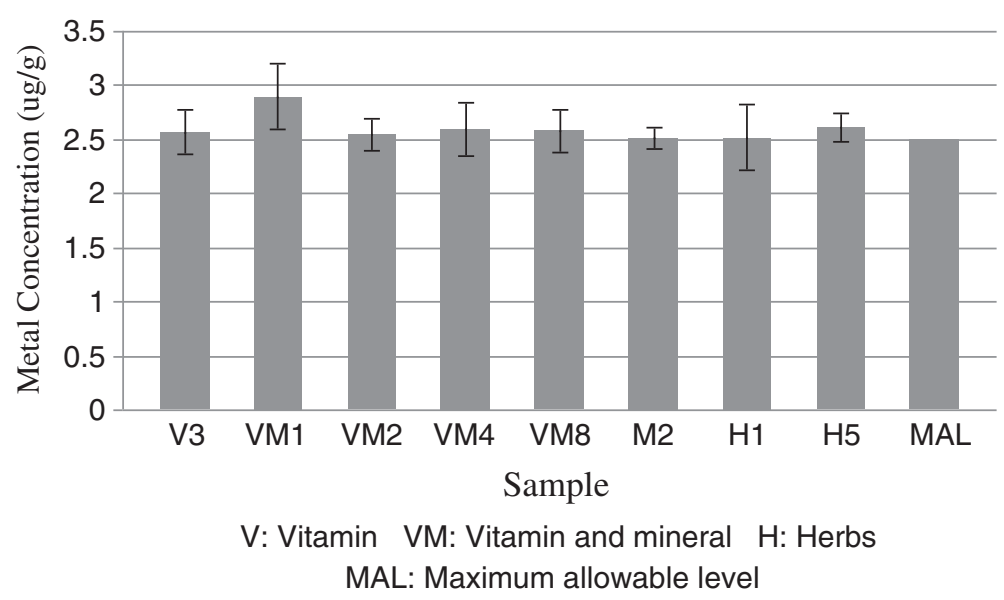

Figure 1 Samples above the maximum allowable $\mathrm{Cd}$ levels.

level of Cd was found in sample VM1 $(2.914 \mu \mathrm{g} / \mathrm{g})$ followed by VM4 with a level of $(2.621 \mu \mathrm{g} / \mathrm{g})$. VM1 is labeled as "essential vitamins and minerals for diabetics", while VM4 as "supplement multicomplex vitamins and minerals". The other 4 samples with high $\mathrm{Cd}$ levels (above MAL) were from the other categories. For example the level in $\mathrm{H} 5$ sample was $2.62 \mu \mathrm{g} / \mathrm{g}$ and is recommended for the wellbeing of the urinary ducts, $\mathrm{H} 1$ of $2.551 \mu \mathrm{g} / \mathrm{g}$ and advised for memory disorder. The high levels of $\mathrm{Cd}$ in these samples resulted most probably from other essential minerals existing in the samples such as $\mathrm{Zn}, \mathrm{Ca}$ and P. A statistical significant correlation existed between the levels of $\mathrm{Cd}$ and $\mathrm{Zn}$ $(\mathrm{r}=0.75, \mathrm{p}<0.01)$, and most samples that had $\mathrm{Ca}$ and/or $\mathrm{P}$ as a constituent had high $\mathrm{Cd}$ levels. For instance, V3 (rich in calcium and phosphorous), H1 sample contains di-calcium phosphate, and $\mathrm{H} 4$ contains calcium phosphate. It is well established that $\mathrm{Zn}$ and $\mathrm{Cd}$ are geochemically related [41], and also $\mathrm{Cd}$ is an out product of phosphate rocks [44-46]. Cadmium and $\mathrm{Ca}$ have similar ionic radii and $\mathrm{Cd}$ can co-precipitates with calcium carbonate and/or has a high affinity for carbonates [40-42]. The daily intake of $\mathrm{Cd}$ in all samples, with a range of $0.03-9.4 \mu \mathrm{g} /$ day is lower than the permitted daily exposure from drugs and dietary supplements (PDE of $25 \mu \mathrm{g} /$ day). Yet 3 samples had higher levels than those calculated from FAO/WHO provisional tolerable intake [47], for a $60 \mathrm{~kg}$ body weight and $10 \%$ allocation due to dietary supplements (Table 4). The studied samples levels were below the MRL level (minimum risk level) of $14 \mu \mathrm{g} /$ day [39]. MRL is an estimate of the daily exposure to a hazardous substance that is likely to be without appreciable risk of adverse non cancer health effects over a specified duration of exposure. Even if Cd levels were below referenced safety and health values, yet due to natural occurrences of $\mathrm{Cd}$ with essential metals $(\mathrm{Ca}, \mathrm{Zn})$, dietary supplements should be checked for content of $\mathrm{Cd}$ in samples that are essential for delivering the nutrients such as $\mathrm{Ca}$ and $\mathrm{Zn}$.

With respect to As, the mean level of all dietary samples was $0.26 \mu \mathrm{g} / \mathrm{g}$, with a range between 0.012 and $0.16 \mu \mathrm{g} / \mathrm{g}$. Nine samples had levels above the newly revised MAL $(0.15 \mu \mathrm{g} / \mathrm{g})$ as set by US Pharmacopeial in 2012 [19]. Mineral and Vitamins samples were highest in As levels, and eight samples had levels above the recommended MAL (Figure 2). The highest As levels was in sample VM3 $(1.621 \mu \mathrm{g} / \mathrm{g})$, which is assigned as multi vitamins and minerals for children. VM10 As level was relatively high $(1.095 \mu \mathrm{g} / \mathrm{g})$ and it is classified as "essential vitamins and minerals for pregnant women". Whereas VM4 (labeled as "supplement of multi vitamins and minerals and does not result in accumulation when taken accordingly") and VM7 (an energizer) had levels of $0.61 \mu \mathrm{g} / \mathrm{g}$, and V1 had a level $0.514 \mu \mathrm{g} / \mathrm{g}$. Furthermore a significant statistical correlation existed between the levels of As and those of $\mathrm{Fe}(\mathrm{r}=0.55, \mathrm{p}<0.05)$ and $\mathrm{Mn}$ $(\mathrm{r}=0.67, \mathrm{p}<0.01)$. The geochemical association between As and Fe, As and Mn has been reported by Goh and Lim [48] and Kim et al. [49]. The mean daily intake of As for all samples was $0.3 \mu \mathrm{g} /$ day, whereas for vitamin and mineral samples it was $0.5 \mu \mathrm{g} /$, with a range of $0.01-1.8 \mu \mathrm{g} /$ day. Two samples had daily As intake values (Figure 3 ) higher than the oral permitted daily exposure (PDE of $1.5 \mu \mathrm{g} /$ day) as revised by USP in 2012 [19]. But the As daily intake levels of all samples is lower than the previous level of $15 \mu \mathrm{g} /$ day set by USP in 2008 [20], and lower than the recommended permissible daily intake by WHO/FAO [50] (Table 4). Furthermore, all samples had lower levels than the MRL level of $21 \mu \mathrm{g} /$ day [39]. Yet even if the levels of As in all our samples were below the referenced values for safety and health, our dietary supplements should be monitored for content of As in dietary samples that have high Fe and Mn as essential nutrient. 


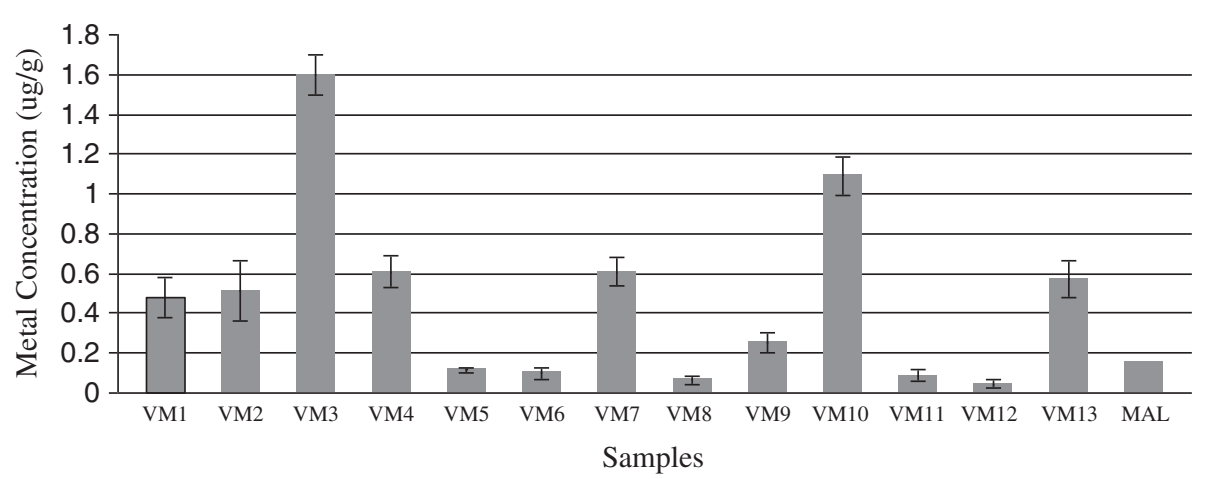

VM: Vitamin and mineral MAL: Maximum allowable level

Figure 2 Levels of As in samples composed of vitamins and minerals.

\section{Conclusions}

- Dietary supplements are generally utilized by most people on voluntary basis and without strict supervision and knowledge of their health/risk factor, in contrast to medications which are under control of Physicians. This project has evaluated the quality of 33 imported dietary supplements in terms of metals consumed by the Lebanese population.

- The sequence of the highest metals' concentrations in all supplements was $\mathrm{Fe}, \mathrm{Zn}$, and $\mathrm{Mn}$ respectively.

- Statistical significant correlations occurred among the three metals ( $\mathrm{Fe}, \mathrm{Zn}$, and $\mathrm{Mn}$ ) indicating that either these minerals are added as supplements or as natural geochemical associations.

- With regard to the micro minerals, $\mathrm{Cr}$ concentrations were found to be less than the international maximum accepted levels. While in some samples, concentrations of Se and Mo were above the accepted limits, yet they were below the daily permitted exposure levels posing no health risk factor. On the other hand, some samples had levels of copper above allowable levels and permitted daily exposure, thus, it is recommended to monitor dietary supplements for their $\mathrm{Cu}$ levels.

- The health hazard effect level of the toxic metals Hg and $\mathrm{Pb}$ was absent in all studied samples.

- In contrast, $30 \%$ of the analyzed samples had levels of $\mathrm{Cd}$ above allowable levels, and were statistically correlated with $\mathrm{Ca}$, and $\mathrm{Zn}$ essential minerals. $62 \%$ of samples had also levels of As above accepted limit and these levels were associated with $\mathrm{Fe}$ and $\mathrm{Mn}$ essential minerals.

- Consequently, supplements consumed as essential nutrient for their $\mathrm{Ca}, \mathrm{Zn}, \mathrm{Fe}$ and $\mathrm{Mn}$ should be monitored for toxic metal levels due to their natural geochemical association with essential metals to ensure the safety of supplement consumptions.

- However, exact justification of this association requires subjecting samples to chemical speciation analysis.

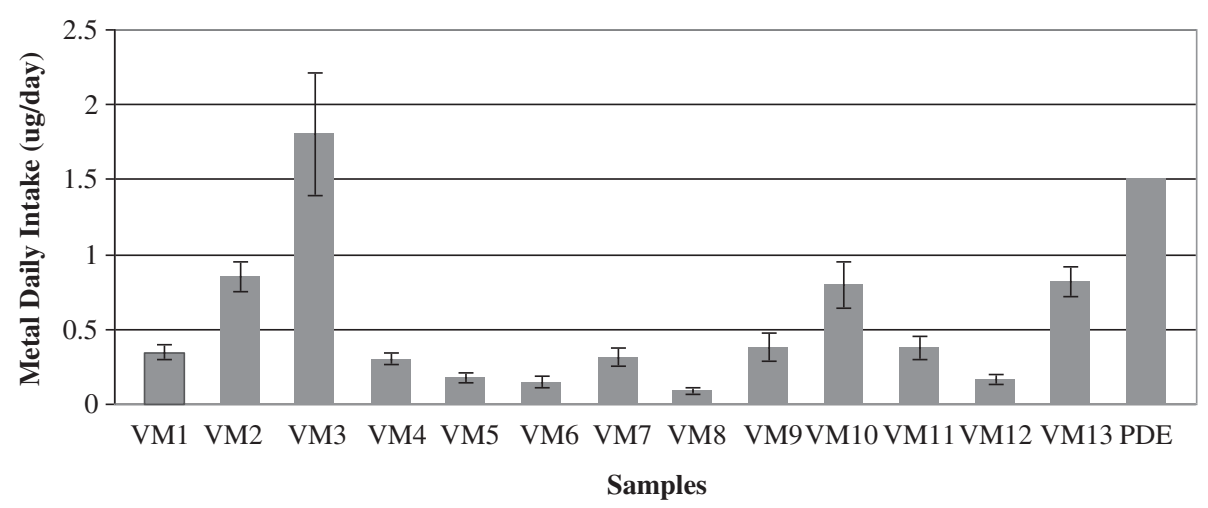

VM: Vitamin and mineral PDE: Permitted daily exposure

Figure 3 Levels of As daily exposure in samples composed of vitamins and minerals. 
Table 5 Percent recovery of reference material by XRF (Expected Value)

\begin{tabular}{|c|c|c|c|c|c|c|}
\hline & $\mathrm{Cu}(\mu \mathrm{g} / \mathrm{g})$ & $\mathrm{Fe}(\mu \mathrm{g} / \mathrm{g})$ & $M n(\mu g / g)$ & Se $(\mu \mathrm{g} /)$ & $\mathrm{Ti}(\mu / g)$ & $\mathrm{Zn}(\mu \mathrm{g} / \mathrm{g})$ \\
\hline Tomato leave Certified (NIST 1573a) & $4.7 \pm 0.14$ & $368 \pm 7$ & $246 \pm 8$ & $14.89 \pm 0.27$ & - & $30.9 \pm 0.7$ \\
\hline Measurement & $4.42 \pm 0.18$ & $371 \pm 9$ & $242 \pm 10$ & $13.12 \pm 0.31$ & - & $31.2 \pm 0.8$ \\
\hline$\%$ Recovery & 94 & 101 & 98 & 88 & - & 101 \\
\hline Soil Certified (NIST 2586) & - & $51610 \pm 890$ & $1000 \pm 18$ & - & $6050 \pm 660$ & $352 \pm 16$ \\
\hline Measurement & - & $48513 \pm 700$ & $903 \pm 27$ & - & $5627 \pm 500$ & $335 \pm 20$ \\
\hline$\%$ Recovery & - & 94 & 90 & - & 93 & 95 \\
\hline
\end{tabular}

\section{Methods}

Reagents and glassware

All reagents used were of analytical reagent grade. High quality water, obtained using a Milli-Q system (Millipore, Direct $Q$ equipped with ultrapure Ion-Ex Cartridge, C.No. QTUM000IX Bedford, MA, USA), was used exclusively).

All glassware was thoroughly cleaned by soaking overnight in $2 \mathrm{M}$ nitric acid and then rinsing thoroughly with MilliQ water, then kept in an oven at $110^{\circ} \mathrm{C}$.

\section{Sample preparation and analysis by EDXRF}

The tablets of each sample and the content of each capsule were grinded, reduced to a fine homogenous powder, sieved using $2 \mathrm{~mm}$ plastic sieve size, and stored in plastic bags for metal analysis.

The concentrations of 6 metals ( $\mathrm{Ca}, \mathrm{Cu}, \mathrm{Fe}, \mathrm{Mn}, \mathrm{Se}, \mathrm{Zn}$ ) in the prepared samples were determined using handheld XRF technique (Niton XL3 GOLLD hand held, Thermo Fisher Scientific) which is energy dispersive $\mathrm{X}$-ray fluorescence (EDXRF) up to $50 \mathrm{kV}$-ray tube source and optimized silicon drift detector (SDD).

\section{Digestion procedures of samples}

Samples of low metal concentrations were analyzed by the digestion method. The digestion procedure involved adding slowly and in portions $50 \mathrm{~mL}$ of freshly prepared 1:1 (v:v) $\mathrm{H}_{2} \mathrm{O}_{2}$ (30\%): $\mathrm{HNO}_{3}(65 \%)$ to one gram of each sample, then covered and kept for 2 days. Each solution was heated till it became clear, then filtered into a $25 \mathrm{~mL}$ lidded plastic tube and diluted with deionized water, next inserted in a water bath at $60^{\circ} \mathrm{C}$ for 30 minutes, and stored at $4^{\circ} \mathrm{C}$. Whereas, for samples that did not form clear solutions, $10 \mathrm{~mL}$ aqua regia was added before heating in oil bath at $120^{\circ} \mathrm{C}$ till clear, then filtered and stored similarly as above.

\section{Analysis by thermal AAS and ICP-MS}

The concentrations of $\mathrm{Cd}, \mathrm{Cr}, \mathrm{Mo}$, and $\mathrm{Pb}$, in the prepared and digested dietary samples were determined by using AAS-Graphite furnace ("Shimadzu" AA-6300) and background correction deuterium lamp. Working standard solutions were prepared by dilution of stock solutions ( $1 \mathrm{mg}$ metal $/ \mathrm{ml}$ in $2 \% \mathrm{HNO}_{3}$, Merick, Germany) with MilliQ water. The instrument detection limits were $\mathrm{Cd}$ : $2 \mu \mathrm{g} / \mathrm{L}, \mathrm{Cr}: 4 \mu \mathrm{g} / \mathrm{L}$; Pb: $3 \mu \mathrm{g} / \mathrm{L}$, and Mo: $30 \mu \mathrm{g} / \mathrm{L}$.

The concentrations of As and $\mathrm{Hg}$ were determined by ICP-MS (Agilent ICP-MS 7500-Ce, Japan). The instrument detection limits on the ICP-MS were $50 \mathrm{ppt}$ for $\mathrm{Hg}$, and 25 ppt for As.

\section{Reliability and efficiency of analytical techniques}

Certified Reference Material (CRM) was used, including Tomato leaves (NIST 1573a) and soil (NIST 2586), to determine the efficiency and accuracy of the analytical methods and digestion procedures. Reference materials were done in triplicates. The recovery percentages based on CRMS for XRF technique are presented in Table 5, and those of metals analyzed by digestion in Table 6 .

Table 6 Percent recovery of reference material by digestion (Expected values)

\begin{tabular}{|c|c|c|c|c|c|}
\hline & As $(\mu \mathrm{g} / \mathrm{g})$ & $\mathrm{Cd}(\mu \mathrm{g} / \mathrm{g})$ & $\mathrm{Cr}(\mu \mathrm{g} / \mathrm{g})$ & $\mathrm{Hg}(\mu \mathrm{g} /)$ & $\mathrm{Pb}(\mu / \mathrm{g})$ \\
\hline Tomato leave Certified (NIST 1573a) & $0.112 \pm 0.004$ & $1.52 \pm 0.04$ & $1.99 \pm 0.06$ & $0.034 \pm 0.004$ & - \\
\hline Measurement & $0.111 \pm 0.008$ & $1.55 \pm 0.06$ & $1.95 \pm 0.05$ & $0.033 \pm 0.006$ & - \\
\hline$\%$ Recovery & 99 & 101 & 98 & 97 & - \\
\hline Soil Certified (NIST 2586) & $8.7 \pm 1.5$ & $2.71 \pm 0.54$ & $301 \pm 45$ & $0.367 \pm 0.038$ & $432 \pm 17$ \\
\hline Measurement & $7.9 \pm 2.1$ & $2.49 \pm 0.47$ & $268 \pm 27$ & $0.342 \pm 0.027$ & $411 \pm 24$ \\
\hline$\%$ Recovery & 91 & 92 & 89 & 93 & 95 \\
\hline
\end{tabular}




\section{Abbreviations}

DI: Daily intake; DIVM: Daily intake of vitamin and mineral; FDA: Food and drug administration; H: Herbs; MAL: Maximum allowable levels; M: Minerals; PDE: Permitted daily exposure; V: Vitamin; VM: Vitamins and minerals; USP: United states pharmacopeia; WHO: Worlds health organization.

\section{Competing interests}

The authors declare no competing interests.

\section{Authors' contributions}

MM have recommended the project and have been involved in drafting the manuscript and revised it critically for soundness of the pharmaceutical concepts. SIK carried the project design, data analysis, interpretations, and prepared the manuscript. TH carried out all experimental procedures and acquisition of data. All authors read and approved the final manuscript.

\section{Acknowledgements}

Mr. Marwan Wehbeh, Chemistry Laboratory Supervisor at LAU for his technical support.

Mr. Yousef Korfali for his assistance in editing the manuscript.

\section{Author details}

${ }^{1}$ Lebanese American University, P.O.Box 13-5053, Chouran Beirut, 11022801 Beirut, Lebanon. ${ }^{2}$ Lebanese American University, P.O. Box 36, Byblos, Lebanon.

Received: 11 October 2012 Accepted: 15 January 2013 Published: 18 January 2013

\section{References}

1. National Institute of Health: What's in the bottle? An introduction to dietary supplement. USA: NCCAM Publication Number D191; 2003.

2. Raman P, Patino LC, Nair MG: Evaluation of metal and microbial contamination in botanical supplements. J Agriculture Food Chemist 2004 52:7822-7827.

3. Garcia-Rico L, Leyva-Perez J, Jara-Marini ME: Content and daily intake of copper, zinc, lead, cadmium and mercury from dietary supplements in Mexico. Food Chem Toxicol 2007, 45:1599-1605.

4. Soriano S, Pereira Netto AD, Cassella RJ: Determination of $\mathrm{Cu}, \mathrm{Fe}, \mathrm{Mn}$, and Zn by flame atomic absorption spectrometry in multivitamin/ multimineral dosage forms or tablets after acidic extraction. J Pharm Biomed Anal 2007, 43:404-410.

5. Gomez MR, Cerutti S, Olsina RA, Silvia MF, Martínez LD: Metal content monitoring in Hypericum perforatum pharmaceutical derivatives by atomic absorption and emission spectrometry. J Pharm Biomed Anal 2004, 24:569-576.

6. FDA (Food and Drug Administration): Dietary Reference Intakes for Vitamin A, Vitamin K, Arsenic, Boron, Chromium, Copper, lodine, Iron, Manganese, Nickel, Silicon, Vanadium, and Zinc. Washington DC: Report of the Panel on Micronutrients, Food and Drug Administration. Dietary Supplements. Center for food Safety and Applied Nutrition, National Academy Press; 2001

7. Mertz W: Interaction of chromium with insulin: a progress report. Nutrition Review 1998, 56:174-177.

8. WHO: Trace elements in human nutrition and health. Geneva: WHO; 1996.

9. Goldhaber SB: Trace elements risk assessment vs. toxicity. Regul Toxicol Pharmacol 2003, 38:232-242.

10. Thomson CD: Assessment requirements for selenium and adequacy of selenium status: a review. Eur J Clin Nutr 2004, 58:391-402.

11. Institute of Medicine. Food and Nutrition Board: Selenium. Dietary reference intakes: Vitamin C, Vitamin E, selenium, and caroteniods. Panel on Dietary Antioxidants and Related compounds, Standing Committee on the Scientific Evaluation of Dietary Reference Intakes, Food and Nutrition Board, Institute of MedicineNational. Washington DC: Academy Press; 2000

12. Kauffman JF, Westenberger BJ, Robertson JD, Guthrie J, Jacobs A, Cummins SK: Lead in pharmeucitical products and dietary supplements. Regul Toxicol Pharmacol $2007,48: 128-134$.

13. Ang $\mathrm{HH}$ : Lead contamination in Eugenia dyeriana herbal preparations from different commercial sources in Malaysia. Food Chem Toxicol 2008 46:1969-1975

14. Ikem A, Egiebor NO: Assessment of trace elements in canned fishes (Mackerel, Tuna, Salmon, Sardine, and Herrings) marketed in Georgia and Alabama (United States of America). J Food Composition Anal 2005, 18:771-787.

15. Obeid PJ, El-Khoury B, Burger J, Aouad S, Younis M, Aoun A, El-Nakat JH: Determination and assessment of total mercury levels in local, frozen, and canned fish in Lebanon. J Environ Sci 2011, 23(9):1564-1569.

16. Kitchin KT, Conolly R: Arsenic-induced carcinogenesis-oxidative stress as a possible mode of action and future research needs for more biologically based risk assessment. Chem Res Toxicol 2010, 23:327-335.

17. Rahman A, Persson LA, Nermell B, El Arifeen S, Ekstrom EC, Smith AH, Vahter M: Arsenic exposure and risk of spontaneous abortion, stillbirth, and infant mortality. Epidemiology 2010, 21:797-804

18. Hsieh YC, Lien LM, Chung WT, Hsieh Fl, Hsieh PF, Wu MM, Tseng HP, Chiou $H Y$, Chen CJ: Significantly increased risk of carotid atherosclerosis with arsenic exposure and polymorphisms in arsenic metabolism genes. Environ Res 2011, 111:804-810.

19. USP: The new USP $<232>$ (Elemental Impurities-Limits) and USP $<233>$ (Elemental Impurities-Procedures). 2012. http://www.chemicalsolutionsltd. com/Cap_USP.htm.

20. USP: General Chapter on Inorganic Impurities: Heavy Metals Stimuli Article, USP Ad Hoc Advisory Panel on Inorganic Impurities and Heavy Metals. 2008. http:// www.usp.org/sites/default/files/usp_pdf/EN/USPNF/2008-0410InorganiclmpuritiesStim.pdf.

21. Tumir H, Bošnir J, Dragun Z, Tomić S, Puntarić D, Jurak G: Monitoring metal and metalloid content in dietary supplements on the Croatian market. Food Control 2010, 21:885-889.

22. Haidar S, Naithani $V$, Barthwal J, Kakkar P: Heavy metal content in some therapeutically important medicinal plants. Bull Environ Contam Toxicol 2004, 72:119-127.

23. Mazzanti G, Battinelli L, Daniele C, Costantini S, Ciaralli L, Evandri MG: Purity control of some Chinese crude herbal drugs marketed in Italy. Food Chem Toxicol 2008, 46:3043-3047.

24. Palmer PT, Jacobs R, Baker PE, Ferguson K, Webber S: Use of Field-Portable XRF analyzers for rapid screening of toxic elements in FDA-regulated products. J Agric Food Chem 2009, 57:2605-2613.

25. Al-Omari S: Determination of essential and toxic elements in ten herbal medicines using energy-dispersive XRF analysis. X-Ray Spectrometry 2011 40:31-36.

26. Perring $L$, Audrey D: EDXRF as a tool for rapid minerals control in milkBased products. J Agric Food Chem 2003, 51:4207-4212.

27. Talbot V, Chang WJ: Rapid multielement analysis of oyster and cockle tissue using X-ray fluorescence Spectrometry with applications to reconnaissance marine pollution investigations. Sci Total Environ 1987, 66:213-223.

28. Sheng-Xiang B, Zhi-Wong W, Jing-Song L: X-Ray-Fluorescence analysis of elements in fruit juice. Spectrochemica Acta B 1999, 54:1893-1897.

29. Al-Bataina BA, Maslt AO, Al-Kofahil MM: Element analysis and biological studies on ten oriental spices using XRF and Ames tests. J Trace Elements Medicinal Biol 2003, 17:85-90.

30. Anderson D: Multielement analysis of housewares and other food -related items by $23 \mathrm{Am}$ radioisotope X-Ray Fluorescence transportable spectrometer and hand held analyzers. J Assoc Official Analytic Chem 2003, 86:583-597.

31. Chuparina EV, Aisueva TS: Determination of heavy metal levels in medicinal plant Hemerocallis Miller by X-ray fluorescence spectrometry. Envi Chem lett 2011 2011, 9(1):19-23.

32. Bueno MI, Romão W: Fingerprinting of sildenafil citrate and tadalafil tablets in pharmaceutical formulations via X-ray fluorescence (XRF) spectrometry. J Pharm Biomed Anal 2012, 56:7-11.

33. USP: General Chapter on Inorganic Impurities: Heavy Metals Stimuli Article. Pharmacopeial Forum 2009, 34(5). http://www.usp.org/sites/default/ files/usp_pdf/EN/hottopics/2009-04-22MetallmpuritiesCommentDigest.pdf.

34. USP: USP Advisory Panel on Metal Impurities Metals and Limits Table. 2009. http://www.usp.org/sites/default/files/usp_pdf/EN/hottopics/2009-0422MetallmpuritiesToxChart.pdf.

35. NSF International: Dietary Supplement-Standard 173, Metal Contaminant Accepted level. USA: NSF International; 2003. http://www.nsf.org/business/ newsroom/pdf/DS_Metal_Contaminant_Acceptance_Levels.pdf.

36. JECFA: Evaluation of certain food additives and contaminants, Twenty-seven report of joint FAONHO Expert committee on food additives.: WHO Technical report Series 696; 1983.

37. Onianwa PC, Adeyemo AO, Idowu OE, Ogabiela EE: Copper and zinc contents of Nigerian foods and estimates of adult dietary intakes. Food Chem 2001, 72:89-95. 
38. JECFA: Evaluation of certain food additives and contaminants, twenty-six report of joint FAO/WHO Expert committee on food additives. Geneva: WHO Technical report Series 683; 1982.

39. Avula A, Wang YH, Duzgoren-Aydin NS, Khan IA: Inorganic elemental composition of commercial multivitamin/mineral dietary supplements: application of collision/reaction cell inductively coupled-mass spectroscopy. Food Chem 2011, 127:54-62.

40. Korfali SI, Davies BE: Speciation of metals in sediment and water in a river underlain by limestone: role of carbonate species for purification capacity of rivers. Advances in Environmental Research 2004, 8:599-612.

41. Korfali SI, Davies BE: Seasonal variations of trace metal chemical forms in bed sediments of a karstic river in Lebanon: implications for selfpurification. Environ Geochem Health 2005, 27:385-395.

42. Korfali SI, Jurdi M: Speciation of metals in bed sediments and water of Qaraaoun Reservoir, Lebanon. Environ Monit Assess 2010, 178:563-579.

43. JECFA: Evaluation of certain food additives and contaminants, Seventy-three report of joint FAO/WHO Expert committee on food additives. Geneva: WHO Technical report Series 960; 2011.

44. Selinus O, Alloway B, Centeno JA, Finkelman RB, Fuge R, Lindh U: Essentials of Medical Geology: Impacts of the Natural Environment on Public Health. USA: Elsevier Academic Press; 2005.

45. Korfali SI, Jurdi M: Suitability of surface water for domestic water use: Awali River case study. European Water 2011, 35:3-12.

46. Korfali SI, Jurdi M: Chemical profile of Lebanon's potential contaminated coastal water. J Environ Sci Eng 2012, A 1:351-363.

47. JECFA: Evaluation of certain food contaminants, Sixty-four 64 report of joint FAO/WHO Expert committee on food additives. Geneva: WHO Technical report Series 930; 2006

48. Goh K-H, Lim T-T: Arsenic fractionation in a fine soil fraction and influence of various anions on its mobility in the subsurface environment. Appl Geochem 2005, 20:229-239.

49. Kim K-W, Chanpiwat P, Hanh HT, Phan K, Sthiannopkao S: Arsenic geochemistry of groundwater in Southeast Asia. Frontiers in Medicine 2011, 5(4):420-443.

50. JECFA: Evaluation of certain food additives and contaminants, Thirty-three report of joint FAO/WHO Expert committee on food additives. Geneva: WHO Technical report Series 776; 1989.

doi:10.1186/1752-153X-7-10

Cite this article as: Korfali et al:: Evaluation of heavy metals content in dietary supplements in Lebanon. Chemistry Central Journal 2013 7:10.

\section{Publish with ChemistryCentral and every scientist can read your work free of charge \\ "Open access provides opportunities to our colleagues in other parts of the globe, by allowing anyone to view the content free of charge." \\ W. Jeffery Hurst, The Hershey Company. \\ - available free of charge to the entire scientific community \\ - peer reviewed and published immediately upon acceptance \\ - cited in PubMed and archived on PubMed Central \\ - yours - you keep the copyright \\ Submit your manuscript here: \\ http://www.chemistrycentral.com/manuscript/<smiles>c1ccccc1</smiles> \\ Chemistry Central}

